
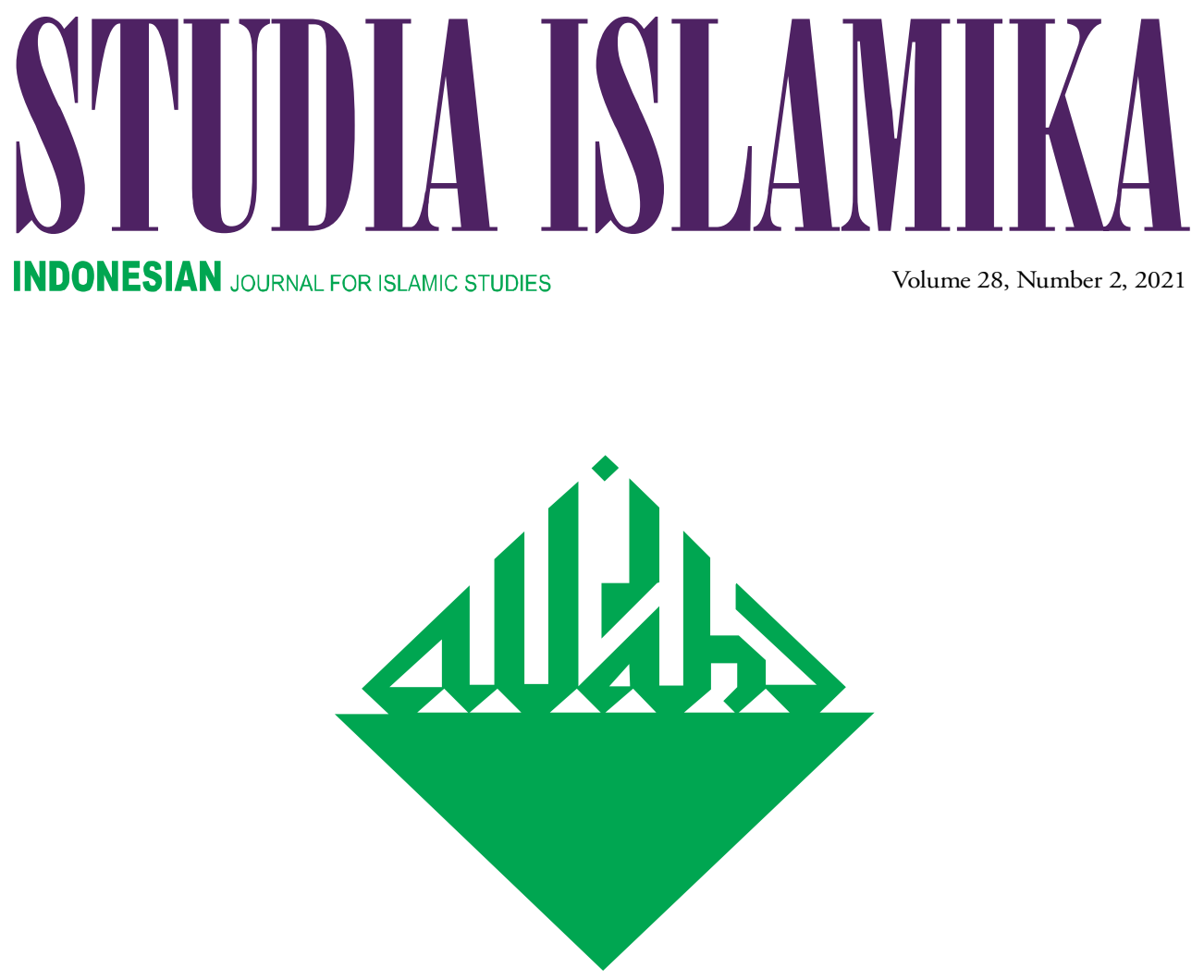

The Word 'Lebai' and Its Ethnic Origins:

Reassessing an EARly Designation for Muslim Religious Officials in the Malay World

Alexander Wain

FORBIDDEN VISIBILITY:

Queer Activism, Shari'a Sphere

and Politics of Sexuality in Aceh

Moch. Nur Ichwan

The Politics of Syariatisation in Indonesia:

MMI and GARIS' Struggle for Islamic LaW

Ratno Lukito 
STIUDLA ISLAMIIIKA 



\section{STIDIIA ISLAVIIIKA}

Indonesian Journal for Islamic Studies

Vol. 28, no. 2, 2021

EDITOR-IN-CHIEF

Azyumardi Azra

MANAGING EDITOR

Oman Fathurahman

EDITORS

Saiful Mujani

Jambari

Didin Syafruddin

Jajat Burhanudin

Fuad Jabali

Ali Munhanif

Saiful Umam

Dadi Darmadi

Jajang Jahroni

Din Wahid

Euis Nurlaelawati

INTERNATIONAL EDITORIAL BOARD

M. Quraish Shihab (Syarif Hidayatullah State Islamic University of Jakarta, INDONESIA)

Martin van Bruinessen (Utrecht University, NETHERLANDS)

John R. Bowen (Washington University, USA)

M. Kamal Hasan (International Islamic University, MALAYSIA)

Virginia M. Hooker (Australian National University, AUSTRALIA)

Edwin P. Wieringa (Universität zu Köln, GERMANY)

Robert W. Hefner (Boston University, USA)

Rémy Madinier (Centre national de la recherche scientifique (CNRS), FRANCE)

R. Michael Feener (National University of Singapore, SINGAPORE)

Michael F. Laffan (Princeton University, USA)

Minako Sakai (The University of New South Wales, AUSTRALIA)

Annabel Teh Gallop (The British Library, UK)

Syafaatun Almirzanah (Sunan Kalijaga State Islamic University of Yogyakarta, INDONESIA)

ASSISTANT TO THE EDITORS

Testriono

Muhammad Nida' Fadlan

Rangga Eka Saputra

Abdullah Maulani

ENGLISH LANGUAGE ADVISOR

Benjamin J. Freeman

Daniel Peterson

Batool Moussa

ARABIC LANGUAGE ADVISOR

Tb. Ade Asnawi

Ahmadi Usman

\section{COVER DESIGNER}

S. Prinka 
STUDIA ISLAMIKA (ISSN 0215-0492; E-ISSN: 2355-6145) is an international journal published by the Center for the Study of Islam and Society (PPIM) Syarif Hidayatullah State Islamic University of Jakarta, INDONESIA. It specializes in Indonesian Islamic studies in particular, and Southeast Asian Islamic studies in general, and is intended to communicate original researches and current issues on the subject. This journal warmly welcomes contributions from scholars of related disciplines. All submitted papers are subject to double-blind review process.

STUDIA ISLAMIKA has been accredited by The Ministry of Research, Technology, and Higher Education, Republic of Indonesia as an academic journal (Decree No. 32a/E/KPT/2017).

STUDIA ISLAMIKA has become a CrossRef Member since year 2014. Therefore, all articles published by STUDIA ISLAMIKA will have unique Digital Object Identifier (DOI) number.

STUDIA ISLAMIKA is indexed in Scopus since 30 May 2015.

Editorial Office:

STUDIA ISLAMIKA, Gedung Pusat Pengkajian

Islam dan Masyarakat (PPIM) UIN Jakarta,

Jl. Kertamukti No. 5, Pisangan Barat, Cirendeu,

Ciputat 15419, Jakarta, Indonesia.

Phone: (62-21) 7423543, 7499272, Fax: (62-21) 7408633;

E-mail: studia.islamika@uinjkt.ac.id

Website: http://journal.uinjkt.ac.id/index.php/studia-islamika

Annual subscription rates from outside Indonesia, institution: US\$ 75,00 and the cost of a single copy is US\$ 25,00; individual: US\$ 50,00 and the cost of a single copy is US\$ 20,00 . Rates do not include international postage and handling.

Please make all payment through bank transfer to: PPIM, Bank Mandiri KCP Tangerang Graha Karnos, Indonesia, account No. 101-00-0514550-1 (USD),

Swift Code: bmriidja

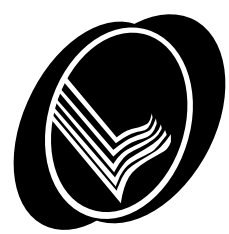

Harga berlangganan di Indonesia untuk satu tahun, lembaga: Rp. 150.000,-, harga satu edisi Rp. 50.000,-; individu: Rp. 100.000,-, harga satu edisi Rp. 40.000,-. Harga belum termasuk ongkos kirim.

Pembayaran melalui PPIM, Bank Mandiri KCP Tangerang Graha Karnos, No. Rek: 128-00-0105080-3 


\section{Table of Contents}

\section{Articles}

253 Alexander Wain

The Word 'Lebai' and Its Ethnic Origins:

Reassessing an Early Designation

for Muslim Religious Officials in the Malay World

283 Moch. Nur Ichwan

Forbidden Visibility:

Queer Activism, Shari'a Sphere

and Politics of Sexuality in Aceh

319 Ratno Lukito

The Politics of Syariatisation in Indonesia:

MMI and GARIS' Struggle for Islamic Law

349 David Efendi, Nanang Indra Kurniawan, Purwo Santoso From Fiqh to Political Advocacy:

Muhammadiyah's Ecological Movement in the Post New Order Indonesia

385 Bambang Qomaruzzaman, Busro Doing Hijrah through Music: A Religious Phenomenon Among Indonesian Musician Community 
413 Muhammad Napis Djuaeni \& Ahmadi Usman

Al-Lughah al-'Arabiyah

fī al-ma'āhid al-Islāmīyah bī Indūnīsīyā:

Mushkilātuhā wa țuruq hallihā

\section{Book Review}

457 Yanwar Pribadi

Kebangkitan Konservatisme Islam:

Politik Identitas dan Potret Demokrasi di Indonesia

\section{Document}

473 Fahmi Imam Fauzy \& Aptiani Nur Jannah Islamic on Screen:

Religious Narrative on Indonesia's Television 
Ratno Lukito

\title{
The Politics of Syariatisation in Indonesia: MMI and GARIS' Struggle for Islamic Law
}

\begin{abstract}
This paper addresses the deficiency of the doctrinal approach in Islamic legal studies. There is an emergent need to comprehend Islamic law from the standpoint of its practical aspects: that is, how the law is intended to produce certain results, whether it gives expected results, and whether an identifiable result is consistent with the reason for the law as one might have expected. This paper examines the discourse of legal Islamization from the perspective of its practical aspects, that is, how the idea is developed, campaigned and impregnated in Muslim societies. A study of the organizations Majlis Mujahidin Indonesia (MMI) and Gerakan Reformis Islam (Garis) shows that both groups had different concern. While MMI focused on the theoretical legal system, Garis was more concerned with practical realm of law; yet the two are the same in orientation as they are both concerned with how everyday life is regulated for Muslims.
\end{abstract}

Keywords: Majlis Mujahidin Indonesia, Gerakan Reformis Islam, Legal Islamization. 
Abstrak: Tulisan ini membahas kekurangan pendekatan doktrinal dalam studi hukum Islam. Ada kebutuhan mendesak untuk memahami hukum Islam dari sudut pandang aspek praktisnya: yaitu, bagaimana hukum itu dimaksudkan untuk menghasilkan hasil tertentu, apakah itu memberikan hasil yang diharapkan, dan apakah hasil yang dapat diidentifikasi konsisten dengan alasan bukum seperti yang diharapkan. Tulisan ini mengkaji wacana Islamisasi hukum dari perspektif aspek praktisnya, yaitu bagaimana gagasan itu dikembangkan, dikampanyekan, dan diresapi dalam masyarakat Muslim. Kajian terhadap organisasi Majlis Mujahidin Indonesia (MMI) dan Gerakan Reformis Islam (GARIS) menunjukkan bahwa kedua kelompok memiliki kepedulian yang berbeda. Sementara MMI fokus pada sistem hukum teoretis, Garis lebih mementingkan ranah hukum praktis; namun keduanya memiliki orientasi yang sama karena sama-sama memperhatikan bagaimana kehidupan sehari-hari diatur bagi umat Islam.

Kata kunci: Majlis Mujahidin Indonesia, Gerakan Reformis Islam, Islamisasi Hukum.

ملخص: تناقش هذه المقالة ما ينقصه النهج العقائدي في دراسة الشريعة الإسلامية.

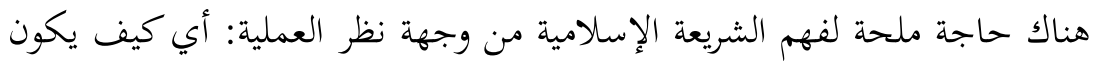

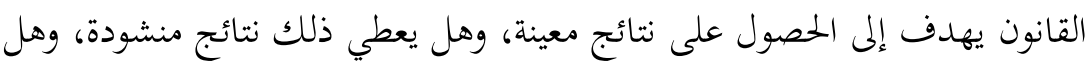

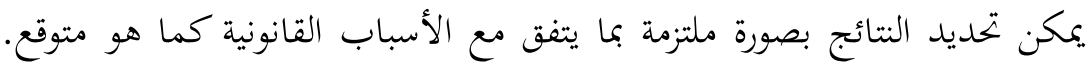

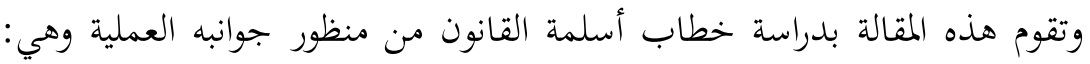

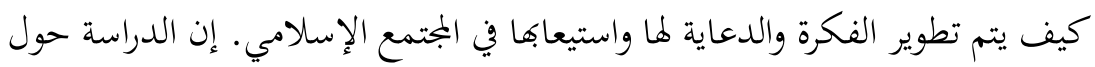

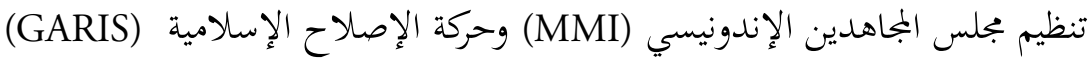

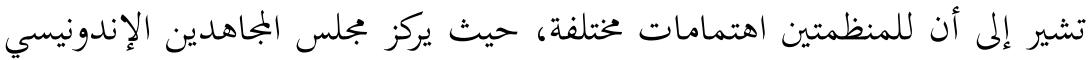

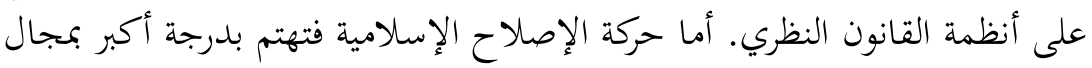

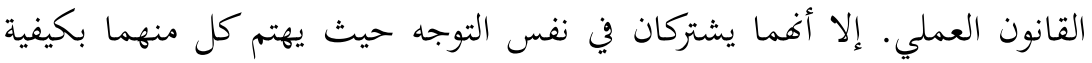
تنظيم الحياة اليومية للمسلمون.

الكلمات المفتاحية: مجلس المجاهدين الإندونيسي، حركة الإصلاح الإسلامي، أسلمة القانون. 
lthough their character varies, the two organizations, Majlis
Mujahidin Indonesia (MMI) in Yogyakarta, Daerah Istimewa
Yogyakarta, and Gerakan Reformis Islam (Garis) in Cianjur, West Java, are rooted in the same philosophical and ontological basis. As Islamic legal hardliners, both share similar concerns in their attitude towards the state and socio-political conditions of Indonesia. In their view, Muslims as the majority population who have had a dominant role in the process of state formation, are always placed at the periphery of social, economic, cultural and political realms. Further, this occurs in a country that was supported by Muslim groups since the earliest stages of the country's development.

This study examines the struggles of MMI and Garis to Islamize the everyday lives of the people as a means of exposing the dialectics between Islamic law and society. This paper addresses two research questions: first, the cognitive aspects of the struggle, namely, the philosophy of legal Islamization conveyed in their understanding of Islamic law and how theoretically the project of legal Islamization should be done; and second, the substantive aspects of Islamization, that is, their approach and method as reflected in the type and pattern of programs implemented. Data were collected from in-depth interviews with the key actors of the two organizations, who were involved in a number of their activities, and an observation of the lives of some MMI and Garis activists.

This paper uses Brian Z. Tamanaha's concept of "Legal instrumentalism" as its theoretical basis ${ }^{1}$ to explore how legal Islamization may be seen as more of a political agenda than a legal endeavor. Following Tamanaha's concept, the Islamization of law in Indonesia's current socio-political context strengthens the political bargaining power of Islamization progenitors vis-à-vis the state. Tamanaha's idea is reinforced by a number of current scholars such as Noah Salomon, Aria Nakissa, and Michael Peletz, who use an anthropological lens to examine Islamic law. How politics are interwoven with law, the economy, and culture in general is examined by Salomon (2016) in an ethnographic study of the Sudanese experience with the Islamic state from its revolutionary establishment in 1989 to the present. Both state and non-state actors established, experienced and contested the same duties across a diverse spectrum of life in Sudan. Nakissa (2019), on the other hand, supports an anthropological approach that combines 
both hermeneutic theory and practice. In his opinion the two can be combined to analyze cultural, legal, and religious traditions. These ideas were developed through an analysis of the Islamic legal tradition, which examines both Islamic legal doctrine and religious education. In order to fully understand the phenomenon, the cognitive and practical aspects of Islamization cannot be separated. Peletz concurred with this view in their examination of why Malaysia has become more punitive in recent decades, someone should plunge themselves into the arena where the myriad dimensions of Shariah often go unnoticed and unpublicized (Peletz 2020, 1-47). In Peletz's Sharia Transformations, an ethnographic, historical, and theoretical approach is used to study the practice and lived experience of Sharia in Malaysia. The three scholars concur with Tamanaha that the law is widely viewed as "an empty vessel to be filled as desired, and to be manipulated, invoked, and utilized in the furtherance of ends" (Tamanaha 2016, 1). That is, the content of the law depends on who is its progenitor and what personal interests they want to advance.

\section{Background of the Organizations}

Although both MMI and Garis have their own distinct historical backgrounds, their formation was inseparable from the context of the Reformation movements that were rising in Indonesian politics since mid 1998 (Fealy 2004, 104-121; Makruf and Halimatussa'diyah 2014, 1-15; Chaq 2013, 16-42; Lukito 2016, 393-425). The two groups also have their own figures, who led the struggle and developed the movement. Despite their different origins, both organizations have been driven by Muslim politicians who had an interest in establishing a local hardliner group to facilitate Islamization. ${ }^{2}$ As the two were driven by the same logic and force of struggle, they were designed to cater to the needs of earlier National Muslim hardliners such as Muhammad Natsir, Anwar Haryono, Sahirul Alim, and others (Dewan Pimpinan Majelis Mujahidin 2001, 3). The establishment of MMI and Garis was therefore imagined by many Muslim activists as a means of blocking new waves of secularism and the general influence of Western neocolonialism (Musonif 2003). Thus, although each organisation was shaped by its locality, their activities and the way in which they disseminated their missions are generally inseparable from Indonesia's other radical groups. 
What differentiates the two organizations are the places in which they were established. MMI was established in Yogyakarta, a pluralistic city and the heart of Javanese culture and tourism, famous also as as an educational destination. Although the idea of Islamization is not foreign in Yogyakarta, given the number of preaching activities in some major universities since 1990s, it does not seem to resonate with the city's people. The city prides itself as a place where pluralistic values are upheld and people from different backgrounds are always welcome, commemorating the eternal amalgamation of Islamic spiritualism with Javanese culture (religion and secularism) reflected in the JavaneseIslam traditions embraced by the Mataram kingdom. The push for Islamization brought by organizations such as MMI has therefore not gained much support from the people of Yogyakarta. It can be said that MMI's missions did not have enough coverage or influence compared to Yogyakarta's pluralistic social and political values, which favour a more moderate adherence to Islam.

In contrast, Garis' local context of Cianjur is a place where the seeds of Islamization had already taken strong roots when Chep Hernawan founded the organization in $2001 .^{3}$ The political condition in the regency was thus conducive to radicalists looking to implement Shari'ah. Cianjur at the time was led by a devout Muslim politician, Wasidi Swastomo, well-known for implementing Islamic values that affect the everyday lives of the people. Swastomo, who was elected as the regent of Cianjur in 2001, was a devout and literalist Muslim whose views of religion were influenced by hardliners. In particular, the state and religion were seen as inseparable and the state as having a necessary role in establishing Shari'ah. This was in line with Garis' main objective to dismantle many practices in society seen as transgressing the principles of Islamic beliefs (Lukito 2016, 397-399).

The local socio-political context that surrounded the establishment of MMI was not convergent with those of Garis in many respects. For Abu Bakar Ba'asyir and other radicalists, ${ }^{4}$ the creation of MMI was driven more by the need to fulfill a national agenda than local factors (Majelis Mujahidin 2001). They wanted to create not just a vehicle to spread political Islam locally. This is because Islamization is a national project that pertains to the whole Muslim population in Indonesia. Islamization should thus be treated as a national program, not just for certain groups of Muslims in local contexts such as the city 
of Yogyakarta (Majelis Mujahidin 2003, 9-29). MMI was born from a national congress in Yogyakarta, which invited many figures from different cities as well as neighboring countries in Southeast Asia. The aggregate missions of Muslim hardliners in the region was to bolster an un-Islamic political system, which seems to have gained momentum at a time when Islamization was seen to address the common needs of all Muslims in Indonesia. The reason behind building the organization in the small city of Yogyakarta is thus not related to local politics but is more in line with the position of the city as a hub of socio-cultural as well as political movements from all over the nation.

For Garis, locality and personality are an important factor. In Hernawan's view, the struggle for Islamization is a remedy for his broken political career in the national arena. Through this struggle, his personal dreams can be realized while also benefiting local movements in Cianjur at the time, which in turn was imagined to reach the wider scope of Islamization across the whole nation. Disappointed with national political vehicles, Hernawan focused his Islamization programs at a grassroots level, on local issues related to the implementation of Islamic teachings. This is why Garis was considered a good partner for local government efforts and in implementing the Islamization program in Cianjur, such as that of "Gerbang Marhamah", because both share basic concerns for detering people from un-Islamic practices. In reality, Garis benefited from the "Gerbang Marhamah" programs, which were used to boost its Islamization agenda. Thus, we can conclude that in contrast to MMI's attitude at its inception, it has since built a frontage with the government, which is seen as secular and hostile to Islam. In its early iteration, Garis, did not create any distance with the state.

\section{Cognitive Shari'ah}

Shariah in the view of Islamic legal hardliners follows natural law teachings, which sees Islam as normative and Islamic law as being divinely ordained and universal (Donnelly 2007, 1-7). The struggle of Islamization is therefore undertaken with a single objective; to bring people into total submission to the One and Only God as He is the Only Law Maker. Shari'ah can thus be understood as a principle or a body of laws understood to have been derived from nature - in this case God's teachings - ethically binding for all human societies in the world. The main objective of any Muslim organization involved Islamization, 
such as Garis and MMI, can never go beyond this principle, that is, to implement Shariah in all aspects of human life, either private or public, so as to arrive at a condition where Islamic law becomes the only source of governance for all of humanity.

Comprehending Shariah in such a way requires adhering to a positivist understanding of law, whereby power and command are united and run hand in hand to establish a regime of law. As the law is essentially a matter of command from the sovereign, the struggle to establish the law involves a lot of emphasis on a zeal of power in establishing the substantive system of the law. This means that the struggle of Islamization can be characterized a political effort, not the application of substantive law as such. That is, Shari'ah intends to mold its political status in the lives of Indonesian citizens. Members of both MMI and Garis understood that Islam would not exist without the political support of Muslims living in the country. That aligns with Abu Bakar Ba'asyir's explication that legal pluralism can be accepted in Islamic law as long as Muslims are the principal demographic. ${ }^{5}$

Both MMI and Garis believe that one of the main problems of Muslim society in Indonesia is their tendency to enact un-Islamic values and traditions found in secular societies (Awwas 2003). The struggle of Islamization is incumbent upon all members of Muslim society. And in this case, Islamization in the realm of law should become the main agenda according to which all Muslims could be brought into one single system of life reflecting the divine values emanated in the Qur'an and Sunnah. This understanding of law and religion can affect the attitude and behavior of many members of these organizations, which initiated programs of Islamization to address the social, cultural and political changes overshadowing the country. There are three perspectives that support a monolithic view of religious law (Ward 2008, 211-228). First, a rigid and textualist view of the Qur'an and Sunnah as the only acceptable source of the law. The two corpuses are regarded as the only legal sources adequate for answering all the problems faced by humanity. Qur'an and Sunnah are treated as textual sources that are in line with the ever changing lives of all societies. That is, the texts are not understood as being bound with the context in which they were revealed or created.

Second, reflecting the belief that Islamic law is an independent legal system free from any social influences, the practice of the religious law is understood as a phenomenon separated from any foreign social and 
cultural traditions. Islam should not be mixed with anything outside the sacred corpus. Legal teachings should thus be derived directly from within the Islamic tradition itself to prevent the amalgamation of the sacred and the profane. As a result, any efforts to innovate systems of Islamic law should be rejected, since such innovations either in ideas or practices will taint pristine sources of the religious law. Third, and related to the second, radical actors share a disapproving attitude towards any legal transgressions or transformations in the body of (classical) Islamic law, despite its encounters with foreign legal traditions and any other extraneous social values existing in society. In line with the view of Islamic law as a closed system, Islamic law is believed not to have any relationship whatsoever with social values commonly found in situ.

The three viewpoints above seem to be shared among actors of radical organizations such as MMI and Garis in Indonesia. They believe that Islamic law should be incorporated into the state, so as to allow Islamic legal traditions and cultural values to filter into society. In this case, the Islamization of law is not seen as a legal project separated from theology, as the two are entertwined in Islam. Rather, it is supported by the proposition that law is basically an ideology. The struggle to incorporate religious law into people's lives is simply another way that politics manifest. In the following sections, we will see that radicalist Islamization projects propogate a theological understanding of Islamic law as a monolithic and all-embracing legal system.

\section{The Substance of the Campaign}

Although MMI and Garis share a belief in the need for Islamization, they pursue substantively different approaches and methods. In contrast to MMI, which tends to focus on the grand ideas and theoretical subjects of the written law, Garis is focused more on the practice of law in the lives of everyday people. That is, while MMI is much more interested in black letter law found in many codes and state laws (ius constitutum), Garis is interested in the practice of those state laws in the lives of common people (law in practice). Although both share their dislike of secular rules and laws created by the state, MMI is concerned with concepts while Garis is concerned with individual practices. The following section canvasses the kinds of Islamization projects that MMI and Garis have pursued to bring Islamic legal values into practice within Indonesia's national legal system. 


\section{MMI's Projects of Legal Islamization}

Monday, August 7, 2000 is an important date in the history of Majlis Mujahidin Indonesia (MMI). Preceded by a National Mujahidin Congress held in Yogyakarta (August 5-7, 2000), it was the date when the declaration was first set forth to establish the MMI movement to realize the project to revive Shari'ah in the everyday life of the country. A number of old hardliner figures came to sign the declaration, such as Deliar Noer, Ali Yafie, Ahmad Mansur Suryanegara, Siddiq Amin, Miftah Farid, Alawy Muhammad and Abdullah Qadir Baraja. The mandate to establish the movement was bestowed upon them. The creation of a mujahidin organization is nonetheless an obligation for the whole ummah as it provides a way to resolve three acute problems faced by Indonesian Muslims. First, while it is understood that the obligation to implement the whole system of Shari'ah is upon all Muslims, the ummah in Indonesia is prone to disunity. Implementing Shariah remains a mere illusion if Muslims in Indonesia are not united. Second, Indonesian Muslims do not have effective leadership. What they have is groups, parties or local leaders who are separated from each other. And third, since Indonesia's independence, a single organization has not proved itself capable to coordinate the Muslim struggle of Shar'iah. The establishment of MMI is thus based on the three lines of reasoning: ideological, historical as well as political (Amrullah 2009, 24-25). The three points above are argued to be necessary preconditions for starting a coordinated Islamization movement. ${ }^{6}$

The hardliners believe that legal Islamization should be incorporated directly into the national legal system, to which the process of lawmaking is bestowed, which in turn can direct people to practice the principles of Shari'ah in their everyday lives. As aforementioned, MMI's legal Islamization programs are focused on the official state law. Although it may be inseparable from the practice of law in the everyday life of the people, at least in its early movements, MMI seemed more interested in challenging the "law in books".

\section{1) Proposal to Amend the 1945 Constitution}

As aforementioned, the main mission of legal Islamization is to create a Muslim society committed to Shariah (tatbiq al-shariah) in all aspects of life. The efforts of MMI are thus focused on maintaining this mission. In relation to the state official law, MMI's initial focus was 
directed towards Islamisizing the legal foundations of Indonesia (Majelis Mujahidin 2001a, 7-8). This focus must be understood contextually. Since its early inception, the movements of the MMI were built upon a common concern about the relationship between Islam and the state in Indonesia. MMI believe that the 1945 Constitution is a reflection of Indonesia's national history, in which Islam plays a great role. The struggle to Islamize the Constitution can, therefore, be understood as an attempt to return to the process of building the constitution when it was first conceived in 1945. MMI intended to remind Indonesians that Shari' ah provides the primary building blocks of the country's legal system, and that aligning the state with its teachings is the first step of a comprehensive process of Islamization.

When reviewed in detail, MMI's proposed amendments do not seek to zealously alter the 1945 Constitution. The modern concept of constitutional legal drafting was followed by MMI, as they have edited the text of the constitution but not its framework. One of the most controversial aspects of the amendment is found in one paragraph of the Constitutional Preamble, which stipulates the five principles of Indonesia known as Pancasila. This was debated by Muslims and secular nationalists in the early stages of independence and in the drafting of the 1945 Constitution. What is vehemently called Piagam Jakarta (Jakarta Charter) in the history of Indonesia's constitutional building was revitalized by MMI in its proposed amendments. Muslims and secularists debated whether the preamble of the constitution should maintain the idea of the seven wonders of the world in the Charter, which mentions the obligation of Muslims to implement Shari'ah or pursue secularism. In this case, however, MMI stepped beyond the seven-world conflict, while remaining aligned with Islamic factions who strongly oppose secularist views. In paragraph 4 of the Preamble the old concept of the constitution states:

“..., yang terbentuk dalam suatu susunan negara Republik Indonesia yang berkedaulatan rakyat dengan berdasarkan kepada: Ketuhanan Yang Maha Esa,..."

(“..., formed in an arrangement of the Republic of Indonesia in which the sovereignty of the people is based on: the belief in God Almighty,...”).

The MMI amendment proposes a new version of the sentence:

“.., yang terbentuk dalam suatu susunan negara Republik Indonesia dengan berdasarkan: Keimanan pada Allah Yang Maha Esa dengan kewajiban 
menjalankan Syariat Islam bagi para pemeluknya dan memberi kebebasan pemeluk agama lain untuk melaksanakan agamanya,..."

(..., formed in an arrangement of the Republic of Indonesia based on: the faith in Allah Almighty with the obligation to carry out Islamic Shari'ah for its adherents and to give freedom of other religions to carry out their religious injunctions,...”) (Majelis Mujahidin 2001a, 7-8).

It is apparent that MMI tried to amalgamate the idea of the old Jakarta Charter with the more modern idea of religious pluralism. It also seems that MMI had rejuvenated the old Masyumi idea of Islamic nationalism, where the freedom of other communities to implement their own religions is to be guaranteed (Platzdasch 2009, 34 onward). Thus, the faith in One and Only God (in this case MMI used the Islamic term "Allah") should be completed with the obligation to implement Shari'ah for all Muslims in the country - certainly an old idea taken from the wording of the Jakarta Charter - plus the relatively new idea of recognizing non-Muslims' rights to implement their religious teachings.

Another part of the amendment is about the right of lawmaking in the country. Chapter 1 , Article 1 and Paragraph 2 of the 1945 Constitution states that: "Kedaulatan adalah di tangan rakyat, dan dilakukan sepenuhnya oleh Majelis Permusyawaratan Rakyat." (Sovereignty is in the hands of the people, and performed entirely by the People's Consultative Assembly). In this case, MMI appeared to be consistent with their mission of political Islam. In the proposal, MMI put forward the wording: "Kekuasaan tertinggi menetapkan hukum di tangan Allah yang Maha Kuasa sedang pengembangan hukum selanjutnya di tangan rakyat, yang dilakukan sepenuhnya oleh Majelis Permusyawaratan Rakyat." (The highest authority to lay down the law is in the hands of God Almighty while the consecutive process of legal development is in the hands of the people, performed entirely by the People's Consultative Assembly) (Majelis Mujahidin 2001a, 9-10).

It is clear that MMI does not support Western democracy, as representing the sovereignty of the people is a key element of democracy in other parts of the Muslim world, particularly in the era of postcolonialization. Challenging Western concepts of democracy, which have provided the philosophical basis for politics in Indonesia and the world in general, is an essential feature of MMI's legal Islamization. According to hardliners, sovereignty is basically in the hands of God, 
and this should be reflected in the authority to make the law. Even if the practice of law-making is done through representative state institutions, the philosophical basis of legal authority should still be given solely to God Almighty.

The MMI amendment also addressed the Presidency. Again, MMI continued an old debate about whether the president of Indonesia should come from the majority group, in this case (Javanese) Muslim. The 1945 Constitution states that that the leader of the country should be an Indonesian citizen, and that their race, gender, religion or ethnicity should not be determinative. Article 6 of the constitution states:

"(1) Presiden adalah warga negara Indonesia asli."(The President is originally a citizen of Indonesia). While the "(2) Presiden dan Wakil Presiden dipilih oleh Majelis Permusyawaratan Rakyat dengan suara terbanyak."

(The President and Vice-President shall be elected by the People's Consultative Assembly by a majority vote).

The Indonesian president and vice president should thus be Indonesian citizens and elected through a formal state institution that has the right to do so. In its amendment, MMI appealed to an old idea desired by many Muslim nationalists:

"(1) President dan Wakil President ialah warga negara Indonesia, laki-laki, sehat jasmani-rohani, muslim yang taat menjalankan Syariat Islam." And, "(2) Presiden and Wakil Presiden dipilih langsung oleh rakyat dan memenuhi kriteria yang tertera dalam ayat 1."

([1] The President and the Vice-President are a citizen of Indonesia, male, healthy physical-spiritual, pious Muslims carrying out the Islamic Shari'ah. And, (2) The President and Vice-President are elected directly by the people and meet the criteria set out in paragraph 1.) (Majelis Mujahidin 2001a, 10-11).

It is apparent that MMI was very bold in promoting their political mission. Even though they accept religious pluralism in which the existence of non-Muslims is recognized (as seen in Paragraph 4 of the Preamble above), they maintain that Indonesia's leader must be Muslim. What is important here is that MMI's framework follows traditional patterns of Islamic legal thinking, which is dominated by patriarchy and the continuity of male leadership. Apart from this focus on gender, MMI's amendment also proposed that the president should be a devout Muslim as it is his responsibility to bring the country in 
line with the command of God. That is why in the text of a formal oath, an elected president must state his willingness to submit to God Almighty. In their amendment, MMI therefore proposed the wording: “..., mengabdi kepada Allah yang Maha Esa,.." (submitting to the One and Only God), inserted in the presidential oath (Majelis Mujahidin 2001a, 11-12; Article 9 of the Constitution).

In conjunction with the proposed amendments above, MMI also invoked the idea of civil rights. In Article 28, civil rights were proposed by the Amendment Team of the MPR. MMI proposed new wordings as follows (Majelis Mujahidin 2001a, 19-22).

On the issue of civil rights MMI focused on bolstering Islamic values in the Constitution. ${ }^{7}$ The proposed amendment conveys the idea of Islamic human rights that many Indonesian hardliners have advocated for. The first relates to the issue of religious rights. MMI believes that Islam guarantees the rights of all people to embrace any religion they believe as right. Yet, apostasy is a criminal action for Muslims. That is why Art 28E Paragraph 1 of the MMI amendment boldly states that "Muslims should not apostate from Islam." This does not apply to non-Muslims who convert to Islam. The idea that the prohibition of apostacy in Islam applies only to Muslims but not vice versa is certainly the typical position taken by most Muslim jurists since the middle era of Islam. The second issue relates to other citizen rights, in particular, the Islamic concept of the five things that Muslims are obliged to defend: religion, life, family/ descendants, property, honor and the health of wits (Art 28G Para 1). This reflects the basic teachings of human rights supported by many Muslim jurists, the foremost progenitor of which is Al-Shātibī (2005, 265-270) as explicated in his well-known fiqh book, al-Muwāfaqāh.

Another controversial issue that MMI proposed was an amendment to an Article about the position of religion. Article 29 of the Constitution sparked tensions about how the state should priortize religion in Indonesia's quasi-secular context. The initial version emphasized the neutrality of the state in matters of religion, although the state should not be understood to be separate from religion. This is what many have termed the "inbetweenness" of Indonesia's relationship with religion; its politics straddle both secularity and religiousity. MMI again boldly proposed the idea of the unity between the state and religion. In Article 29 of the amendment, MMI proposed two clear messages regarding the inseparability of state and religion: 
"(1) Negara berkewajiban untuk mengatur dan mengawasi agar warga negara Indonesia menjalankan ibadah sesuai dengan ajaran agama masingmasing. (2) Negara menjamin kemerdekaan tiap-tiap penduduk untuk memeluk agamanya masing-masing dan untuk beribadat menurut agama yang dipeluknya."

((1) The State is obliged to organize and oversee that Indonesian citizens to worship in accordance with the teachings of their respective religions.

(2) The State guarantees the freedom of each citizen to profess his/her own religion and to worship according to the religion he/she follows) (Majelis Mujahidin 2001a, 22).

These proposed amendments adhere to the position taken by many Muslim groups about the relationship between the state and religion. These groups believe that secularism does not fit with the character of the country, and that separating the state from religion can jeopardize the historical, sociological and philosophical values that the foundaing fathers of Indonesia held. Finally, MMI proposed an amendment to the Article about economic issues and social welfare. MMI re-emphasized the importance of identifying Islamic values in the constitution, even if the substance of the amendment does not differ greatly from the original. In Article 33, MMI proposed that the more Islamic term "halal" (lawful) be inserted: "(1) Perekonomian disusun sebagai usaha bersama atas asas kekeluargaan dan bersifat halal." (The economy is structured as a joint venture on the basis of family principles and lawful). Although MMI only added one term "halal" (lawful) in this paragraph, it appears to be concerned with the construction of Indonesia's economic system and ensuring that it is aligned with Islamic teachings in the future (Majelis Mujahidin 2001a, 24).

\section{2) The Draft of Penal Law}

Not long after organizing a seminar on the amendment of 1945 Constitution, MMI held another national seminar to discuss the penal law system in Indonesia. Held on July 272002 in Yogyakarta, the seminar was conveyed the objective of the program, namely, to discuss and submit proposed penal law amendments to the government, which at the time applied the penal system adapted from the Dutch model of Wetboek van Strafrecht. ${ }^{8}$ In MMI's perspective Indonesia's secular penal law system has dragged the nation into moral crisis and insecurity, leaving it more vulnerable to criminal attitudes and actions. MMI believed that criminal law adopted from Western systems cannot address moral 
crimes that occur in people's everyday lives. MMI sought to Islamize the penal law system to save the Indonesian people and to achieve the five objectives of creating the nation under Islamic doctrine. First, the objective of guaranteeing the people's freedom to embrace religion (bifz al-din); second, protecting reason from any negative influences in life (bifz al-'aql); third, guaranteeing the sanctity of descent, so there is no doubt about someone's genealogy ( hifz al-nash); fourth, protecting and ensuring the safety of human life, both their individual and species ( $h$ if $z$ al-nafs); and fifth, guaranteeing and protecting the property rights of the people, both as a personal or collective right ( $h i f z$ al-māl) (Majelis Mujahidin 2002, 4; Shātibiy 2005, 270).

Separate to the draft of 1945 Constitutional amendment, the draft of penal law amendment appeared more overarching, encompassing the whole idea of penal law adapted from figh books and the opinions of many Muslim jurists. There are at least four topics presented in the draft of the amendment: general definitions, crime and legal responsibility, crime and punishment, and judicial institutions. It is from the chapter on the definition of some penal law terms that we can understand the general picture of the penal law substantiated in the amendment. The draft submitted here reflects the model of penal law as understood by traditional Muslim jurists; there are no less than 72 terms proposed in the draft that convey traditional patterns of penal law such as: "diyat", "irsy", "habs", "qisas", “'awrah", "hasyimah”, "hirabah", to just mention a few. ${ }^{9}$ Criminal law students may not find these terms in modern system of penal law as they are found in classical Islamic penal law (figh jinayah). In the first chapter of the MMI draft, the terms used can be grouped into three categories: (1) terms that specifically deal with the person who committed the crime or was involved in it, including their character and status; (2) terms that relate to the kinds and methods of crime and punishment; and (3) terms that relate to the object of crime (Majelis Mujahidin 2002, 11-16).

The draft amendment conveys in detail its proposed changes to crime and punishment, which are found in primary sources of Islamic law. MMI accepts legal positivism here because the draft amendments are all structured in the form of modern state law. The draft itself is structured as a state act, whereby the chapters and paragraphs are arranged using the model of the state law (Undang-undang). Thus, in the early articles of the first chapter, the explanation is about the kinds 
of crime found in Islamic penal law. Article 4 (Para 1-3) explains the three general types of crime deserving of punishment in Islam. The three crimes are categorized based on whether the legal sources (Qur'an and Hadith) already subscribe them or not. First, crimes which the sacred text already mentions. These are categorized as hadd (limit or boundary), i.e., punishment for offenses for which limits have been defined in the Qur'an and Sunnah of the Prophet. Thus, it is believed that the Qur'an and Prophetic traditions had been revealed to name the crimes as well as their punishments. The second type of crime is characterized as qișass (equality, retaliation or retribution), which is explained in both the Qur'an and Sunnah. The third is any kind of crime beyond the ones mentioned as hadd or qișass, which the sacred texts do not mention whatsoever. Thus the punishments subscribed may be developed by the government to prevent any negative effects of the crime. This is called Tazir (chastisement), a class of criminal penalties which are defined by the state or ruler, in contradistinction to hudüd, which are prescribed by God (Majelis Mujahidin 2002, 19).

This reflects the basic theory of crime and punishment found in the old figh books of penal law, which MMI adapted using the language of the modern law. A key question is which of the crimes are categorized into the three criteria detailed above. MMI is consistent in its commitment to the classical Muslim jurists' theories, and not the more modern views of Islamic penal law. For example, Article 9 states that there are six crimes that fall into the category of hadd: theft (sariqah), brigandage (biräbah), adultery (zinā), false accusation of unchastity (qadhf), wine drinking (shurb), and religious conversion (riddah) (Majelis Mujahidin 2002, 20-30). Articles 10 to 28 explain in great detail the definitions of those crimes defined as hadd and what kinds of punishment should be subscribed. MMI tried to adapt the classical views of Islamic penal law using the language and method of modern legal drafting; however it is somewhat awkward as it uses a number of terms that do not appear in Indonesian law and/or are not used in Indonesian language. For example, in Article 11 the punishment for stealing is defined as a crime if the perpetrator steals a minimum one-fourth Dinar of gold or three Dirham of silver equivalent to 4.450 gram of gold (Majelis Mujahidin 2002, 21). The use of the terms Dinar and Dirham is not common in Indonesia as MMI followed the classical fiqh books on Islamic penal law written in Arabic. 
This can also be found in the method of punishment ascribed to the hiräbah. The crime of hiräbah is considered to be a capital crime in Islam; as such, the punishment is very harsh. MMI proposed a very old method of punishment: crucifixion and cutting the hand and foot crosswise. Article 14 of the draft states that this punishment should be used for the crime of hirabah. If the robbery involves the homicide, the criminal should be punished with a dead penalty and then the body will be crucified (Para a); otherwise, the death penalty is done without the crucifixion (Para b). The crosswise cutting of hand and foot is used if the robbery does not follow with the killing (Majelis Mujahidin 2002, 23, para c). This kind of harsh physical punishment can also be found in the controversial method of rajam or stoning to death for people who engage in an illicit sexual relationship. In Article 16, stoning to death is subscribed for married people who engage in extra-marital sexual intercourse. The Article even states that: "If the person doing the adultery is married, then that person is punished by stoning, which is thrown with stones measuring at large fist to death" (Majelis Mujahidin 2002, 25; italic added). Whipping is implemented if the adulterer is unmarried, plus expulsion for a year (Para 2). It is clear that MMI ascribes to old ideas of crime and punishment as established in classical books of Islamic penal law. There is little regard for reformulating definitions of crime and punishment in line with modern values.

Chapter two of the proposal is clear in its proposition that the Islamic concept of penal law can be divided into three kinds of crime under Islam. As aforementioned, these are: hadd crimes, qișās crimes and $t a^{\prime} z i r$. The first and second are believed to be based on the primary sources of the law (Qur'an and Sunnah of the Prophet), while the third is a discretionary punishment, as it is not clearly defined in sacred legal texts. The state authority and judge therefore have the discretion to hand down a punishment that is seen as equal to the crime perpetrated (Majelis Mujahidin 2002, 17-34). It is clear that MMI has not reformulated much of the proposed penal law, as much of the Articles and paragraphs mimic those found in classical Islamic texts, particularly those regulated by sacred sources of law. Chapters three and four focus on crime and punishment as well as the judicial institutions that carry out the punishment. However, in Articles 43-68 (Majelis Mujahidin 2002, 37-51), the views of the old Muslim jurists are dominant, indicating that there is very little modern influence in the proposed 
amendment. MMI's Islamization can therefore be characterized as an effort to rematerialize the old substance of Islamic penal law, despite the modern methods of legal drafting used. Thus, because the substance remains unaltered, MMI's attempt to revive Islamic penal law can only be seen as a way to re-instigate the corpus of the law even if the method adopted to do so is modern.

\section{Garis's Projects of Legal Islamization}

The origins of Garis in Cianjur are not as clear as MMI's in Yogyakarta. This does not appear to be an issue for Garis members, who place greater emphasis on the agenda and programs of the organization than ceremonial aspects. Garis was founded in 2001 when the zeal of Islamization was at its highest. The main founder, Chep Hernawan, appeared more concerned about starting the struggle of Islamization rather the context in which Garis was founded. In general, Garis is less organized compared to the more structured model of MMI. The origins of each organisation has influenced their characters. The two mass activities discussed below reflect Garis' reputed focus on instigating the Islamization process.

\section{1) Challenging Ahmadiyah}

Garis paid a lot of attention to Ahmadiyah movements in Indonesia as it provided a good starting point for substantiating their missions in the majority Sunni Muslim Cianjur. The debates surrounding Ahmadiyah was at its height in 2005, allowing Garis to be very active in vigorously disproving of Ahmadiyah. Hernawan explicitly expressed his intention to repress Ahmadiyah movements in Cianjur and its surrounding areas. The legal Islamization program that Hernawan facilitated should take priority in order to revive Islamic teachings and prevent Muslims from straying from the true path brought by the Prophet Muhammad. Legal Islamization is in this case understood as an attempt to protect (Sunni) Islam from any foreign faith and teachings viewed as straying from the orthodoxy.

Garis' hostility towards the Ahmadiyah movement was demonstrated in its attack of a number of Ahmadiyah compounds on September 19 2005. It was a concerted attack purposefully done to demolish four Ahmadiyah villages, Penyairan, Cicakra, Neglasari and Ciparay. It was recorded that 43 houses, 4 mosques, 5 small groceries 
and countless other properties were destroyed in one attack (Hasani et all 2001, 128). Garis involved hundreds of members and inflicted physical as well as psychological harms on the victims. Many believe Garis' zealous character led it to commit violent and threatening acts against Ahmadiyah. Garis' violent actions escalated due to its perceived obligation to reprimand any Muslim groups or denominations that it saw as going against Sunni Islam. However, many felt that Garis' anti-Ahmadiyah actions were politically reasonable. Since early 2005, Cianjur was in the midst of local elections for a new regent. At the time, the regent Wasidi Swastomo was going to run for a second term.

In other words, Garis' escalation of its attack against the Ahmadiyah during a period of political instability may not just be attributed to religious purposes. Rather, it can be characterized as more political. Garis' destruction of Ahmadiyah villages in Cianjur was not possible without the political support of local authorities. Swastomo himself cleverly tried to win the heart of many Muslim constituents in the city by promulgating a General Letter of Decision (Surat Keputusan Bersama), which he claimed to have been made with the support and agreement of the Indonesian Council of Ulama (Majlis Ulama Indonesia, MUI) and about 40 mass organizations in Cianjur. The Letter made it clear that the Ahmadiyah group was forbidden in Cianjur. The Decision Letter was issued just ten days after the Garis attack in Ahmadiyah villages; undeniably reflecting their determination to wipe out the minority group from the region. Both state and non-state actors worked to hand in hand to repress Ahmadiyah.

In Indonesia, debates about the Ahmadiyah have consumed Muslims. In the view of orthodox Sunnite Muslims, belief in prophecies following the prophet Muhammad is a big deviancy; this is why Ahmadiyah is considered to have diverged from mainstream Islam. The belief in the prophecy following Prophet Muhammad implies that besides his Sunnah there may still be another that can be treated as a a second source of Islamic law after the Qur'an. This damages the basic tenets of Islam. Garis' hostility towards Ahmadiyah relates to a perennial concern in Islam about validating a successor to the Prophet Muhammad himself as being equal to the Prophet as the main agent of law-making in Islam. Legal Islamization as understood by Garis rests on the struggle to secure the true source of Islamic law, particularly the Sunnah of the Prophet Muhammad, who is believed to not have a 
successor. The Ahmadiyah belief in the prophecy after Muhammad is a religious deviation that Muslim jurists and intellectuals view as having departed beyond the true understanding of Islam. Efforts to challenge Ahmadi teachings can, therefore, be seen as a religious struggle because such beliefs are considered to be blasphemous. In that case, Garis should be praised in its efforts to implement Law No. 1 of 1985 against religious blashphemy, particularly Article 1 .

\section{2) Anti-Christianization}

Christian proselytization is an issue that has been of concern since Indonesian independence. The threat of successful Christian proselytization in Indonesia haunts the consciousness of many Indonesian Muslims. This is not far-fetched as the Indonesian census has indicated a decline in the number of Muslim citizens in the last three decades. It is not surprising to see that Christianization has became a hot topic of debate among many Muslim figures and organizations in West Java, particularly in the wake of the foundation of Garis in 2001. It is against this backdrop that Garis pursued its objectives. In the view of Hernawan, Christian people ignore the country's rules about religious preaching activities, particularly the Jointly Ministerial Regulation (Surat Peraturan Bersama) between the Minister of Religion and Home Minister No. 8 and 9 of 2006, which regulates religious preaching in Indonesia.

Garis' anti-Christianization is understood to be part of its legal Islamization agenda because it relates to how the state law protects the right of Muslims to uphold their belief in Islam, which is part of their basic human rights. The Amended 1945 Constitution states that the State must guarantee all persons freedom of worship (Art. 29 Para 2). Christian preaching of non-Christians, particularly Muslims, contravenes the Constitution because it is an attack on someone's belief, even if done with soft persuasion. As aforementioned, Christianization also contravenes the principle of religious management regulated in the Jointly Ministerial Regulation (Surat Peraturan Bersama) between the Minister of Religion and Home Minister No. 8 and 9 of 2006, which implements principles of religious segregation, both in the place of worship as well as the area of preaching activities, to keep religious pluralism in harmony.

In July 2007, Garis organised a momumental movement against Christianization. Hernawan effectively organized the movement to 
mark his leadership of Garis and to bolster his image as a local hardliner. On July 20 2007, about 1000 Garis members attacked a Christian valley called Lembah Karmel, a religious compound used as a place for spiritual retreats and praying as well as religious activities for Catholic priests, youth, and people from many other places in West Java. ${ }^{10}$ The existence of the Karmel valley itself was indeed a controversial issue for a number of years, particularly when the compound was being built to cover more than 600 hectares of land over a mountainous area in the village of Cikanyere, the district of Sukaresmi, Cianjur regency.

The compound building was highly controversial due to environmental issues, such as access to water for people in villages surrounding the valley, and the right of people to source wood from national forests near the Karmel Valley. It became a religious issue due to increased suspicion among Muslims in Cianjur and surrounding areas that the Karmel was developed to become like the "Indonesian Vatican", where national Christianization programs are planned and established, not just a place for spiritual activity. ${ }^{11}$

In Hernawan's view, a lot of legal violations were committed in the Karmel complex that people were not aware of, and legal authorities did not address those crimes effectively. Suspicion about Karmel as a center for Christianization had spread all over Cianjur a number of years before. In fact, concerns about Christianization had even reached the local government office of the Cianjur regency. It was Wasidi Swastomo himself, the top executive of the city at the time, who directly sent the letter advising the foundation that owned the Karmel complex to respond to the issue. Through an official letter No. 4532/2580/Kesbang, dated August 1 2005, Swastomo had given a warning to Karmel for not altering status of the complex as a place of Christian religious worship, as it had not initially been registered as such. In the letter, the regent also reprimanded them for not reporting any crimes related to SARA (an Indonesian acronym denoted for suku [tribe], agama [religion], ras [race/ethnic] and antar kelompok [intergroup]). Karmel ignored these warnings.

Furthermore, according to Hernawan, Lembah Karmel had contravened Presidential Decision No. 114 of 1999 on the Spatial Management of Bogor, Puncak and Cianjur (Bopunjur) Regions. ${ }^{12}$ Karmel was not supposed to erect any building that destroyed trees in the surrounding valley that functioned as a water reserve and 
to stop flooding in the region. Article 12 clearly states that no one is allowed to erect any building that damages the forest reserve; the Karmel compound broke the law because it involved the building of housing, churches, chapels, restaurants and stores in the forest reserve. ${ }^{13}$ Moreover, Hernawan attacked many who were not convinced about the wrongdoings of Karmel. He questioned how Karmel could build a church in the middle of the majority Muslim city of Cianjur. Hernawan suggested that they must have ignored the Jointly Ministerial Regulation (SKB) between the Minister of Religion and Home Minister No. 8 and 9 of 2006. He reasoned that it is not inappropriate that a few Christians were able to build a huge church on an empy hill, as the number of Christians required to do so did not fulfil the criteria explicated in the Regulation. ${ }^{14}$ Thus, for many, the Karmel compound was illegal under state rules. ${ }^{15}$

On the day of the attack, the appearance of many Garis members at the Karmel complex was a big surprise. At the time, a committee of an international conference Tritunggal Mahakudus was planned to be held on July 24-29 2007, inviting around 2,500 people from the Christian denomination from all over the country. They were preparing to organize the conference and an alumni meeting. The situation was chaotic because hundreds of Garis demonstrators rammed into the compound and forced the Christians to halt any activities. The police were unable to stop them. A Garis demonstrator explained that the attack was done to halt Christianization programs that were being held in the valley. ${ }^{16} \mathrm{He}$ believed that the compound had been used for a long time to proselytize Christianity throughout Indonesia. Although the veracity of this claim is not clear, many Garis members involved in the attack believed in it. The attack was effective as it stopped all activities in the complex. Hundreds of Christians in the Karmel complex felt mocked and physically abused by the Garis demonstrators. It is not clear how many people were wounded and to what extent the Karmel properties that had been destroyed, as news about it had been repressed. However the attack led to the cancellation of the international conference and other activities.

One should not ignore the violent approach used to bolster Garis' Islamization efforts. Although it remains unclear whether there was an existing program of Christianization in the Karmel valley, ${ }^{17}$ the attack created discomfort and distress among Christians in the area and the 
region in general. One Christian informant expressed that he felt alienated as a member of a religious minority living in Cianjur. ${ }^{18}$ They felt that their basic human right to practice their religion had been violated. Garis' grassroots approach to Islamization used oppressive methods against religious minorities.

\section{Conclusion}

This paper has analyzed contemporary movements working to Islamisize Indonesia's legal system. MMI and Garis were discussed as case studies of how Islamization can be pursued. Both organizations seem to have confined their purpose to Islamization, following the understanding that Islamic teachings should form the foundation of constitutional law as well as the basis of the Indonesia's legal system. However, they carry out the struggle through different approaches. Since its inception, MMI has endeavored to Islamisize the foundation of Indonesia's legal system. Their movements thus focus on official state laws, such as the Constitution. This is most apparent in their proposals to amend the 1945 Constitution and Basic Penal Law in the early 2000s. Garis, on the other hand, are focused on the law in its more general meaning; the term "law" is thus used in its broadest sense to refer to the normative values and practices of everyday life. Islamic law is thus understood to relate to the more practical aspects of Islamic values in the everyday lives of the people.

Thus, MMI is concerned with the theoretical and formal legal underpinnings of Indonesia, while Garis is focused on the realm of non-formal law and practice. However, there is no need to separate the scope of their struggle. MMI and Garis both see the law as divine, and not only as a system of dealing with wordly matters. Law for them emanates all aspects of life, from matters of personal belief to the public realm, such as the penal law system. Both organizations believe that the public and private domains of law are inseparable, as they both come under the umbrella of religious law. This is why the actors of legal Islamization are concerned with ensuring that it is fluid so that it can accomplish its purpose.

In understanding the phenomenon of legal Islamization, one should therefore not limit their analysis to the positivistic idea of law where law and legal institutions are understood as merely a product of the state. The domination of the Westphalian ideology of law in Indonesian 
legal studies is inadequate for comprehensively understanding legal Islamization. It is thus incumbent upon us to understand legal Islamization from the perspective of its actors. As such, our study of legal Islamization should include both an analysis of how state laws are being aligned with Islamic values and how religious law is sought to be incorporated into everyday life. This brings us to anthropological studies of Islamic law, which allows us to both examine formal Islamic law as well as its disparate and informal normative values.

This paper has argued that the law is essentially the product of political bargaining. Using Tamanaha's concept of "Legal instrumentalism" as its theoretical basis, this paper has sought to examine the political agendas of legal Islamization. The Islamization of law in Indonesia's current socio-political context seeks to strengthen the political bargaining power of the progenitors of Islamization. Islamization is used as an instrument of power to advance the personal interests and political agendas of individuals and groups. Thus, the shape that legal Islamization takes reflects the means by which those individuals and groups seek to maximise their power. The development of the law is not the main agenda of Islamization; if it was, Islamist organisations such as MMI and Garis would treat the law as a minor part of their objectives.

This paper also argued that the anthropology of Islamic law is suited to the study of legal Islamization. Whether it is research conducted by Noah Salomon, Aria Nakissa or Michael Peletz, it supports our understanding that Islamic law must be studied from both theortical and practical standpoints. The theoretical and methodological aspects of Islamization cannot be separated. Therefore, the use of 'thick description' is an important tool in the study of Islamic law; that is, when we conduct qualitative research, we must pay attention to contextual details when observing and interpreting social meaning. In this paper, a 'thick description' of the Islamization of law has shown that the historical, political and social context in which actors are located has influenced their practice of Islamization, which took the form of both a da'wah and a political movement. 


\section{Endnotes}

- The author would like to express a deep gratitude to the office of Research and Development (Lembaga Penelitian dan Pengabdian Masyarakat), State Islamic University Sunan Kalijaga Yogyakarta, from which partial funding was given to support the field research of this study. All mistakes found in this paper are however the sole responsibility of the author.

1. Brian Z. Tamanaha, Law as a Means to an End (Cambridge: Cambridge University Press, 2006), p. 1. As saying: “...people see law as an instrument of power to advance their personal interests or the interests or policies of the individuals or groups they support. Today, law is widely viewed as an empty vessel to be filled as desired, and to be manipulated, invoked, and utilized in the furtherance of ends."

2. For MMI, there were Abu Bakar Ba'asyir, M. Thalib and Irfan Awwas, to mention just a few, who worked vigilantly since the organization's foundation to realize its mission. For Garis, there is Chep Hernawan, who can be characterized as the founding father and the main actor of the organization. Both organizations are different in character but deal with similar concerns. MMI in Yogyakarta seems to have culminated from the struggle of a number of Muslim figures concerned with Islamization, while in Cianjur Garis appears to be dominated by one local figure who drove the whole force of movement.

3. Hernawan's personality is controversial in Cianjur. One informant said that he is actually a hoodlum (preman) and local businessman who does not hold firm religious faith. For him, it is all just about business. (Interview with one anonymous Cianjur figure, February, 24, 2017).

4. Abu Bakar Ba'asyir was the chief of the MMI in 2002.

5. Interview with Abu Bakar Ba'asyir on July 24, 2009.

6. "Strategi Perjuangan Majelis Mujahidin" at http://www.majelismujahidin.com/about/ strategi-perjuangan-majelis-mujahidin/.

7. 28E: "(1) Setiap orang berhak memeluk agama dan beribadat menurut agamanya, dan bagi muslim tidak boleh murtad dari Islam. (2) Setiap orang berhak menyatakan pikiran dan sikap, berhak memilih pendidikan dan pengajaran, memilih pekerjaan, memilih kewarganegaraan, memilih tempat tinggal di wilayah negara dan meninggalkannya, serta berhak kembali dalam batas-batas yang dibenarkan oleh ajaran agama."("(1) Everyone has the right to embrace religion and to worship according to their religion, and the Muslims should not be an apostate from Islam. (2) Everyone has the right to express thoughts and attitudes, entitled to choose one's education, employment, citizenship, choosing a place to stay in the territory of the country and left, as well as the right to return within the limits justified by religious teachings.")

28F: "Setiap orang berhak untuk berkomunikasi dan memperoleh informasi sesuai dengan undang-undang." ("Everyone has the right to communicate and obtain information in accordance with the law.")

28G: "(1) Setiap orang berhak atas perlindungan terhadap agamanya, nyawanya, keluargal keturunannya, hartanya, kehormatan dan kesehatan akalnya." "(1) Everyone has the right to the protection of religion, life, family / descendants, property, honor and the health of his wits.")

28H: "(2) Setiap orang berhak memperoleh kemudahan dan perlakuan yang sama untuk memperoleh keadilan.”("(2) Everyone has the right to gain the ease and equal treatment to obtain justice.")

28J: "Di dalam menjalankan hak dan kebebasannya, setiap orang wajib tunduk kepada pembatasan yang ditetapkan dengan undang-undang." ("In carrying out the rights and freedoms, everyone shall be subject to the restrictions established by law.") 
8. Wetboek van Strafrecht voor Nederlandsch-Indie was the criminal code in the Dutch colonial era of Indonesia, in force since January 1, 1918. On the history of Indonesian penal law system (Siong 1961).

9. Diyat: compensation, Irsy: the amount of money to be paid as compensation towards the harmed person, habs: the place or area where the convict carries out the ta'zir punishment, qisas: retaliation, 'awrah: a part of body ordered to be covered, hasyimah: wounding that causes bone injury, hirabah: acts that cause chaos in society that it interferes with the public (Majelis Mujahidin 2002, 11-16).

10. The news on the case can be found in many newspaper and websites, for instance in http://news.detik.com/berita/807482/ribuan-muslim-protes-konferensi-di-lembahkarmel-cianjur.

11. See for instance, http://nizmaanakku.blogspot.co.id/2007/07/lembah-vatikan-karmeldi-cianjur.html

12. The Presidential Decision can be accessed at http://www.bpn.go.id/Publikasi/PeraturanPerundangan/Keputusan-Presiden/keputusan-presiden-nomor-114-tahun-1999-533.

13. The explanation as such can be found in http://nizmaanakku.blogspot.co.id/2007/07/ lembah-vatikan-karmel-di-cianjur.html.

14. According to the Jointly Ministerial Regulation between Minister of Religious Affairs and Home Minister No. 8 and 9 of 2006, Articles 14-16, the construction of the place should be supported by the evidence that there are at least 90 members of the concerned religious group and 60 local residents of another religious belief who approved the building, aside from approval from the local government.

15. Interview with Hernawan on July 10, 2016.

16. Interview with one anonymous Garis member on July 10, 2016.

17. One Christian informant said that the idea that Christianization was propagated through the Karmel complex was not based on fact.

18. Interview with one anonymous Christian figure on July 15, 2016.

\section{Bibliography}

Amrullah, Baizar. 2009. "Upaya Majlis Mujahidin Memformalisasikan Syari'at Islam dalam Lembaga Negara." Unpublished Undergraduate Thesis. Yogyakarta: UIN Sunan Kalijaga.

Awwas, Irfan Suryahardy. 2003. 10 Musuh Cita-Cita Menuju Indonesia Baru Berlandaskan Islam. Yogyakarta: Wihdah Press.

Al-Bayhāqiy, Aḥmad ibn Husayn Abū Bakr. 2003. Al-Sunan al-Kubrā. ed. by Muḥammad 'Abd al-Qadīr Atā. Beirut: Dār al-Kutub al-'Ilmiyyah.

Buehler, M. 2007. “The Rise of Shari'a by-laws in Indonesian Districts: An Indication for Changing Pattern of Power Accumulation and Political Corruption". South East Asia Research, 16(2).

Al-Bukhāry, Muḥammad ibn Ismā'īl. 2001. Al-Jāmi‘ al-Ṣaḥ̄ḥ. ed. by Muḥammad Zuhayr ibn Naṣir. Jeddah: Dār Tawq al-Najāḥ.

Bush, R. 2008. "Regional Sharia Regulations in Indonesia: Anomaly or 
Symptom?". in Greg Fealy and Sally White (eds). Expressing Islam: Religious Life and Politics in Indonesia. Singapore: ISEAS.

Chaq, Moh. Dliya’ul. 2013. "Pemikiran Hukum Gerakan Islam Radikal: Studi atas Pemikiran Hukum dan Potensi Konflik Sosial Keagamaan Majelis Muhajidin Indonesia (MMI) dan Jama'ah Anshorut Tauhid (JAT). Tafaqquh 1(1).

Crouch, M. 2009. "Religious Regulations in Indonesia: Failing Vulnerable Groups". Review of Indonesian and Malaysian Affairs, 43(2).

Donnelly, Bebhinn, 2007. A Natural Law Approach to Normativity. London: Ashgate Publishing.

Fealy, Greg. 2004. "Islamic Radicalism in Indonesia: The Faltering Revival?" Southeast Asian Affairs.

Hasani, Ismail, et all. 2001. Radikalism Agama di Jabodetabek \& Jawa Barat: Implikasinya terhadap Jaminan Kebebasan Beragama/Berkeyakinan. Jakarta: Publikasi Setara Institute.

Jamhari and Jajang Jahroni (eds). 2004. Gerakan Salafi Radikal di Indonesia. Jakarta: Rajawali Pers and PPIM.

Kamil, S and CS. Bamualim (eds). 2007. Syariah Islam dan HAM: Dampak Perda Syariah Terhadap Kebebasan Sipil, Hak-hak Perempuan dan Non-Muslim. Jakarta: CSRC.

Lau, Martin. 2014. "The Re-Islamization of Legal Systems.” in Rudolph Peters and Peri Bearman (eds). The Ashgate Research Companion to Islamic Law. England and Burlington: Ashgate.

Lazuardi, T. 2006. "Gerbang Marhamah: Gerakan Pembangunan Masyarakat Berakhlakul Karimah (Agenda Penerapan Syariat Islam di Cianjur).” Harmoni Jurnal Mutikultural \& Multireligious 17(5).

Lukito, Ratno. 2016. "Islamisation As Legal Intolerance: The Case of GARIS in Cianjur, West Java." Al-Jamiah: Journal of Islamic Studies 54(2).

Majelis Mujahidin, Dewan Pimpinan. 2001. Mengenal Majlis Mujahidin. Yogyakarta: Markaz Pusat Majelis Mujahidin.

- 2001a. Usulan Amandemen UUD '45 Disesuaikan dengan Syariat Islam. Yogyakarta: Markaz Pusat Majelis Mujahidin.

- 2002. Usulan Undang-Undang Hukum Pidana Republik Indonesia Disesuaikan dengan Syariah Islam. Yogyakarta: Markaz Pusat Majelis Mujahidin.

- 2003. Pedoman Umum \& Pelaksanaan Majelis Mujahidin: Untuk Penegakan Dewan Pimpinan Majelis Mujahidin, Syariat Islam. Yogyakarta: Dewan Pimpinan Majelis Mujahidin.

Makruf, Jamhari and Iim Halimatussa'diyah. 2014. "Shari'a and Regional 
Governance in Indonesia: A Study of Four Provinces.” Australian Journal of Asian Law, 15(1).

Musonif. 2003. "Islam sebagai Dasar Negara Menurut Majelis Mujahidin Indonesia." Unpublished Undergraduate Thesis, Faculty of Ushuluddin. Yogyakarta: IAIN Sunan Kalijaga Yogyakarta.

Nakissa, Aria. 2019. The Anthropology of Islamic Law: Educations, Ethics and Legal Interpretation of Egypt's Al-Azhar. Oxford: Oxford University Press.

Peletz, Michael G. 2020. Sharia Transformation: Cultural Politics and the Rebranding of an Islamic Judiciary. Oakland, California: University of California Press.

Pipes, Daniel. Spring 2000. "Islam and Islamism: Faith and Ideology". The National Interest No. 59.

Platzdasch, Bernhard. 2009. Islamism in Indonesia: Politics in the Emerging Democracy. Singapore: ISEAS.

Salomon, Noah. 2016. For Love of the Prophet: An Ethnogrpahy of Sudan's Islamic State. Princeton and Oxford: Oxford University Press.

Setda Kabupaten Cianjur, Bagian Hukum. 2004. Peraturan Daerah Kabupaten Cianjur Nomor: 07 Tahun 2004 Tentang: Pengelolaan Zakat. Cianjur.

2006. Peraturan Daerah Kabupaten Cianjur Nomor: 03 Tahun 2006 Tentang: Gerakan Pembangunan Masyarakat Berakhlaqul Karimah. Cianjur.

Al-Shāṭibiy. 2005. Al-Muwāqāt fì Ușūl al-Sharīáh. Cairo: Dār al-Hadīth.

Shepard, William E. Aug 1987. "Islam and Ideology: Towards a Typology". International Journal of Middle East Studies 19,3.

Siong, Han Bing. 1961. An Outline of the Recent History of Indonesian Criminal Law. The Netherlands: Springer-Science+Business Media, B.V.

"Strategi Perjuangan Majelis Mujahidin.” Situs Resmi Majelis Mujahidin. http:// www.majelismujahidin.com/about/strategi-perjuangan-majelis-mujahidin/.

Tamanaha, Brian Z. 2006. Law as a Means to an End. Cambridge: Cambridge University Press.

Tasman. 2005. "Implementasi Syariat Islam: Studi Program Pembangunan Gerbang Marhamah di Cianjur, Jawa Barat". Unpublished Master Thesis, Faculty of Social and Political Sciences. Jakarta: University of Indonesia.

Teitelbaum, L.E. 1985. "An Overview of Law and Social Research.” Journal of Legal Education 35.

Temby, Quinton. April 2010. "Imagining an Islamic State in Indonesia: From Darul Islam to Jemaah Islamiyah.” Indonesia No. 89.

Triana, W. 2008. "Islamists Rule: the Implementation of Shari'a in Cianjur". Unpublished Master Thesis. Jakarta: Syarif Hidayatullah State Islamic 
University.

Ward, Ken. 2008. “Indonesian Terrorism: From Jihad to Dakwah?”. in Greg Fealy and Sally White (eds). Expressing Islam: Religious Life and Politics in Indonesia. Singapore: ISEAS.

\section{Interviews}

Interview with Abu Bakar Ba'asyir, July 24, 2009.

Interview with Chep Hernawan, July 23, 2016.

Interview with Hernawan on July 10, 2016.

Interview with an anonymous Christian figure in Cianjur on July 15, 2016.

Interview with an anonymous Cianjur figure, February, 24, 2017.

Interview with an anonymous Garis member on July 10, 2016.

Ratno Lukito, Sunan Kalijaga State Islamic University (UIN) of Yogyakarta, Indonesia.Email: ratnolukito@yahoo.com; or ratno.lukito@uin-suka.ac.id. 


\section{Guidelines}

\section{Submission of Articles}

tudia Islamika, published three times a year since 1994, is a bilingual (English and Arabic), peer-reviewed journal, and specializes in Indonesian Islamic studies in particular and Southeast Asian Islamic studies in general. The aim is to provide readers with a better understanding of Indonesia and Southeast Asia's Muslim history and present developments through the publication of articles, research reports, and book reviews.

The journal invites scholars and experts working in all disciplines in the humanities and social sciences pertaining to Islam or Muslim societies. Articles should be original, research-based, unpublished and not under review for possible publication in other journals. All submitted papers are subject to review of the editors, editorial board, and blind reviewers. Submissions that violate our guidelines on formatting or length will be rejected without review.

Articles should bewritten in American English between approximately 10.000 words including text, all tables and figures, notes, references, and appendices intended for publication. All submission must include 150 words abstract and 5 keywords. Quotations, passages, and words in local or foreign languages should be translated into English. Studia 
Islamika accepts only electronic submissions. All manuscripts should be sent in Ms. Word to: http://journal.uinjkt.ac.id/index.php/studiaislamika.

All notes must appear in the text as citations. A citation usually requires only the last name of the author(s), year of publication, and (sometimes) page numbers. For example: (Hefner 2009a, 45; Geertz 1966, 114). Explanatory footnotes may be included but should not be used for simple citations. All works cited must appear in the reference list at the end of the article. In matter of bibliographical style, Studia Islamika follows the American Political Science Association (APSA) manual style, such as below:

1. Hefner, Robert. 2009a. "Introduction: The Political Cultures of Islamic Education in Southeast Asia," in Making Modern Muslims: The Politics of Islamic Education in Southeast Asia, ed. Robert Hefner, Honolulu: University of Hawai'i Press.

2. Booth, Anne. 1988. "Living Standards and the Distribution of Income in Colonial Indonesia: A Review of the Evidence." Journal of Southeast Asian Studies 19(2): 310-34.

3. Feener, Michael R., and Mark E. Cammack, eds. 2007. Islamic Law in Contemporary Indonesia: Ideas and Institutions. Cambridge: Islamic Legal Studies Program.

4. Wahid, Din. 2014. Nurturing Salafi Manhaj: A Study of Salafi Pesantrens in Contemporary Indonesia. PhD dissertation. Utrecht University.

5. Utriza, Ayang. 2008. "Mencari Model Kerukunan Antaragama." Kompas. March 19: 59.

6. Ms. Undhang-Undhang Banten, L.Or.5598, Leiden University.

7. Interview with K.H. Sahal Mahfudz, Kajen, Pati, June $11^{\text {th }}$, 2007.

Arabic romanization should be written as follows:

Letters: ', $b, t, t h, j, h, k h, d, d h, r, z, s, s h, s, d, t, z, ', g h, f, q, l$, $m, n, h, w, y$. Short vowels: $a, i, u$. long vowels: $\bar{a}, \overline{\mathrm{i}}, \overline{\mathrm{u}}$. Diphthongs: aw, ay. Tā marbūtāe $t$. Article: al-. For detail information on Arabic Romanization, please refer the transliteration system of the Library of Congress (LC) Guidelines. 
ستوديا إسلاميكا (ISSN 0215-0492; E-ISSN: 2355-6145) مجلة علمية دولية محكمة تصدر عن مركز دراسات الإسلام والمجتمع (PPIM) بجامعة شريف هداية الله الإسلامية الحكومية بجاكرتا، تعنى بدراسة الإسلام في إندونيسيا خاصة وفي جنوب شرقي آسيا عامة. وتستهدف المجلة نشر البحوث العلمية الأصيلة والقضايا المعاصرة حول الموضوع، كما ترحب بإسهامات الباحثين أصحاب التخصصات ذات الصلة. وتخضع جميع الأبحاث المقدمة للمجلة للتحكيم من قبل لجنة مختصة.

تم اعتماد ستوديا إسلاميكا من قبل وزارة البحوث والتكنولوجيا والتعليم العالي بجمهورية إندونيسيا باعتبارها دورية علمية (رقم القرار: 32a/E/KPT/2017).

ستوديا إسلاميكا عضو في CrossRef (الإحالات الثابتة في الأدبيات الأكاديمية) منذ ع ا • ب، وبالتالي فإن جميع المقالات التي نشرتا مرقمة حسب معرّف الوثيقة الرقمية (DOI). ستوديا إسلاميكا بجلة مفهرسة في سكوبس (Scopus) منذ .ب مايو 0 . ب.

$$
\begin{aligned}
& \text { قيمة الاشتر الك السنوي خارج إندونيسيا: }
\end{aligned}
$$

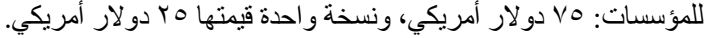

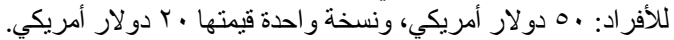

$$
\begin{aligned}
& \text { والقيمة لا تشمل نفقة الإرسال بالبريد الجوي. ونسي. }
\end{aligned}
$$

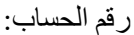

$$
\begin{aligned}
& \text { خارج إندونيسيا (دولار أمريكي): ابن }
\end{aligned}
$$

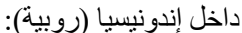

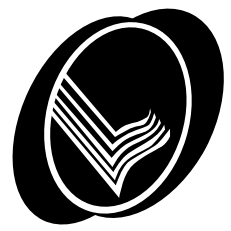




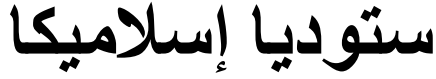 \\ مجلة إندونيسيا للار اسات الإسلامية

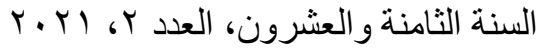

$$
\begin{aligned}
& \text { رئيس التحرير : } \\
& \text { أزيوماردي أزرا } \\
& \text { مدير التحرير: } \\
& \text { أومان فتح الرحمن } \\
& \text { هيئة التحرير: } \\
& \text { سيف المزاني } \\
& \text { جمهاري } \\
& \text { ديدين شفرالدين } \\
& \text { جاجات برهان الدين } \\
& \text { فؤاد جبلي } \\
& \text { علي منحنف جيفي } \\
& \text { سيف الأمم } \\
& \text { دادي دارمادي } \\
& \text { جاجانج جهراني } \\
& \text { دين واحد } \\
& \text { ايويس نورليلاواتي } \\
& \text { محمد قريش شهاب (جامعة شريف هداية الله الإسلامية الحكومية بجاكرتا) } \\
& \text { مارتين فان برونيسين (جامعة أتريخة) }
\end{aligned}
$$

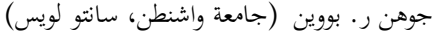

$$
\begin{aligned}
& \text { محمد كمال حسن (الجامعة الإسلامية العالمية - ماليزيا) }
\end{aligned}
$$

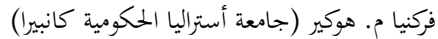

$$
\begin{aligned}
& \text { إيدوين ف. ويرنجا (جامعة كولونيا، ألمانيا) } \\
& \text { روبيرت و ـ هيفنير (جامعة بوستون) ويرنا }
\end{aligned}
$$

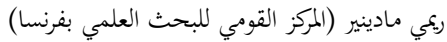

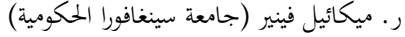

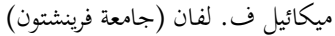

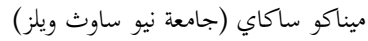

$$
\begin{aligned}
& \text { انابيل تيه جالوب (المكتبة البريطانية) } \\
& \text { شفاعة المرزانة (جامعة سونان كاليجاغا الإسلامية الحكومية) } \\
& \text { مساعد هيئة التحرير: - مسئ } \\
& \text { تيستريونو } \\
& \text { محمد نداء فضلان تئرنان } \\
& \text { رنغكا إيكا سافوترا } \\
& \text { عبد الله مولاني } \\
& \text { مراجعة اللغة الإنجليزية: }
\end{aligned}
$$

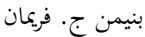

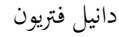

$$
\begin{aligned}
& \text { موسى بتول } \\
& \text { أحمدي عثمان }
\end{aligned}
$$





\section{لالتوايا السال|مسيا}




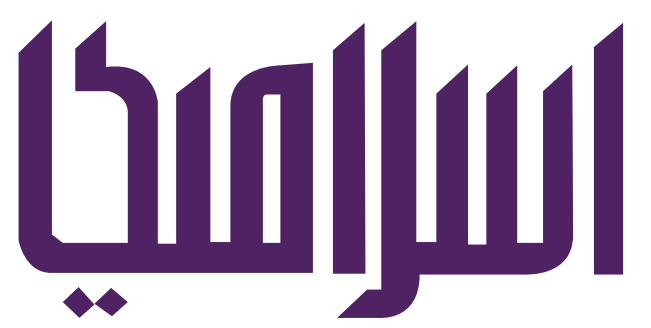

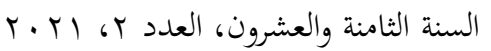

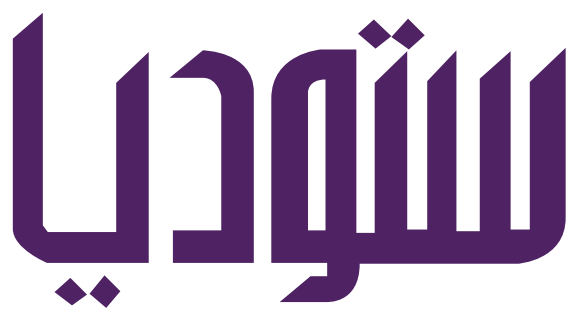

بحلة إندونيسية للدراسات الإسلامية

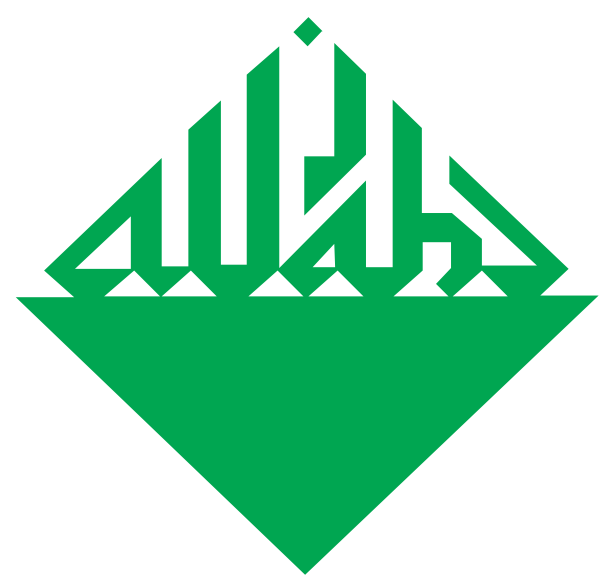

From Fiqh to Political Advocacy:

Muhammadiyah's Ecological Movement

in the Post New Order Indonesia

David Efendi, Nanang Indra Kurniawan, Purwo Santoso

Doing Hijrah Through Music:

A Religious Phenomenon

Among Indonesian Musician Community

Bambang Qomaruzzaman \& Busro

\section{اللغة العربية}

ثهيى المعاهد الإسلاهية بإنكونميسيا:

هشكلاتهما وطرةت حلهما

محمد نفيس جويني وأحمدي عثمان 